\title{
The level of physical activity of university students in Lublin, Bialystok and Covilhã
}

\section{Poziom aktywności fizycznej studentów uczelni wyższych w Lublinie, Białymstoku oraz Covilhã}

\author{
Mariola Król ${ }^{1, C-D \oplus}$, Jolanta Grażyna Zuzda ${ }^{2, A-B, E-F \oplus}$, Rui Miguel Brás ${ }^{3, A-B} \oplus$, \\ Magdalena Rewerska-Juśko ${ }^{1, C-D \oplus}$, Robert Latosiewicz ${ }^{1, A-B, E-F} \oplus$ \\ ${ }^{1}$ Medical University, Lublin, Poland \\ 2 University of Technology, Białystok Poland \\ ${ }^{3}$ Universidade da Beira Interior (UBI), Covilhã, Portugal \\ A - Research concept and design, B - Collection and/or assembly of data, C - Data analysis and interpretation, \\ $D$ - Writing the article, E - Critical revision of the article, F - Final approval of article
}

Król M, Zuzda JG, Brás RM, Rewerska-Juśko M, Latosiewicz R. The level of physical activity of university students in Lublin, Bialystok and Covilhã. Med Og Nauk Zdr. 2020; 26(4): 372-377. doi: 10.26444/monz/130510

\section{Abstract}

Objectives. The aim of the study is to determine the level and to compare the physical activity of students of the Medical University (MU) in Lublin and the University of Technology (BUT) in Bialystok, Poland, and the University of Beira Interior (UBI) in Covilhã, Portugal.

Materials and method. A group of 823 people were examined: 108 students of the Medical University of Lublin, 118 students of Bialystok University of Technology, and 597 students of the University of Beira Interior in Covilhã. The study examined the level of student activity using the IPAQ questionnaire.

Results. With reference to people (both women and men) studying at the MU in Lublin and at UBI in Portugal, the activity level was high, $60.2 \%$ and $51.8 \%$ respectively. In the group of BUT students sufficient activity prevailed $-30.5 \%$ of the respondents. Insufficient activity level was characterized by $2.8 \%$ of MU students, $23.7 \%$ of BUT students and $12.7 \%$ of surveyed Portuguese students. Considering the gender of respondents, statistically significant differences in activity levels among Portuguese students were observed. A sufficient level of physical activity was characterized by a higher percentage of men than women, $37.5 \%$ and $33.8 \%$, respectively.

Conclusions. Students of the Medical University (MU), as well as Portuguese students, were characterized by a high level of physical activity, while students of the Bialystok University of Technology (BUT) had an adequate level of physical activity. Among women studying at MU, BUT and UBI in Portugal, the highest average energy expenditure values were related to walking effort. Among both women and men studying at MU, BUT and at UBI in Portugal, the lowest average values of energy consumption were for moderate activity. Students from MU spent less time sitting during one working day than BUT andUBI Portuguese students.

\section{Key words}

Poland, Portugal, the International Physical Activity Questionnaire IPAQ, student activity

\section{Streszczenie}

Cel pracy. Celem pracy było określenie poziomu oraz porównanie aktywności fizycznej studentów Uniwersytetu Medycznego w Lublinie, Politechniki Białostockiej oraz Universidade de Beira Interior w Covilhã (Portugalia).

Materiał i metody. W badaniu poziomu aktywności wzięły udział 823 osoby - 108 studentów kierunku fizjoterapia oraz kierunku dietetyka Uniwersytetu Medycznego w Lublinie (UM), 118 studentów kierunku turystyka i rekreacja Politechniki Białostockiej (PB) oraz 597 studentów kierunku wychowanie fizyczne w Universidade de Beira Interior Covilhã (Portugalia). Badania przeprowadzono z wykorzystaniem krótkiej wersji Międzynarodowego Kwestionariusza Aktywności Fizycznej (International Physical Activity Questionnaire - IPAQ).

Wyniki. Biorąc pod uwagę studentów PB oraz UM, wystarczającym poziomem aktywności fizycznej charakteryzował się większy odsetek kobiet niż mężczyzn - odpowiednio 55,6\% i 37,5\% studentów PB oraz 42,3\% i 23,3\% studentów UM. Wysokim poziomem aktywności fizycznej cechował się większy odsetek mężczyzn niż kobiet, zarówno w grupie studentów PB, jak i UM. W odniesieniu do osób studiujących na PB wynosił on odpowiednio 31,3 i 29,6\%, natomiast wśród osób studiujących na UM - $73,3 \%$ oraz $55,1 \%$.

Wnioski. Studenci UM oraz z Portugalii charakteryzowali się wysokim, natomiast studenci PB wystarczającym poziomem aktywności fizycznej. Wśród kobiet studiujących na UM, PB oraz w Portugalii najwyższe średnie wartości wydatku energetycznego dotyczyły wysiłku związanego z chodzeniem. Zarówno wśród kobiet, jak i mężczyzn studiujących na UM, PB oraz w Portugalii najniższe średnie wartości zużycia energetycznego dotyczyły aktywności umiarkowanej. Studenci z UM spędzali mniej czasu na siedzeniu w ciągu jednego dnia roboczego niż studenci PB oraz z Portugalii.

\section{Słowa kluczowe}

Polska, Portugalia, Międzynarodowy Kwestionariusz Aktywności Fizycznej IPAQ, aktywność fizyczna studentów 


\section{INTRODUCTION}

Physical activity is defined as any movement of the body generated by skeletal muscles requiring energy expenditure $[1,2,3]$. Any form of activity with a minimum of moderate intensity has a positive effect on the health of the body, and improves the quality of life of people with chronic diseases $[4,5,6,7]$. According to data from the World Health Organization (WHO), experts recommend the accumulation of a half-hourly moderate-intensity physical activity for five days a week, or a minimum of twenty-minute intensive effort performed three times a week. A weekly physical activity recommended for people aged 18-64 is moderate-intensity exercise lasting at least 150 minutes, or high-intensity physical activity for at least 75 minutes, or a combination of moderate and high-intensity exercise $[8,9,10,11,12]$. Physical activity can be measured using several tools, among them questionnaires for checking the sports activity of children, adults aged 16-65, and the elderly, as well as assessing the impact of the level of physical activity on risk factors of diseases $[13,14,15]$.

\section{MATERIALS AND METHOD}

The study aimed to determine the level and compare the physical activity of students of the Medical University in Lublin and the Bialystok University of Technology, and the Universidade de Beira Interior in Covilhã, Portugal. The study of the level of activity was carried out on 823 people: 108 students of physiotherapy and dietetics at the Medical University of Lublin (MU), 118 students of tourism and recreation at Bialystok University of Technology (BUT), and 597 students of physical education at the University of Beira Interior Covilhã, Portugal. In the group of UM students, there were 78 women and 30 men aged $19.33 \pm 1.15$ years, in the group of BUT students 54 women and 64 men aged 20.53 \pm 2.28 years were examined, while in the group of students from Portugal there were 283 women and 314 men aged 20.72 \pm 2.21 years. Detailed anthropometric characteristics of the studied groups are presented in Table 1 .

The study was conducted using a short version of the International Physical Activity Questionnaire (IPAQ, which consists of seven questions relating to each type of physical activity, whether related to everyday life functioning, as

Table 1. Anthropometric characteristics of the examined groups of students by gender and age $(n=823)$

\begin{tabular}{lllccccc}
\hline \multirow{2}{*}{ Variables } & \multicolumn{2}{c}{ Male } & \multicolumn{2}{c}{ Female } & \multicolumn{2}{c}{ Total } \\
\cline { 2 - 8 } & & \multicolumn{1}{c}{$\mathrm{M}$} & $\mathrm{SD}$ & $\mathrm{M}$ & $\mathrm{SD}$ & $\mathrm{M}$ & SD \\
\hline \multirow{3}{*}{ MU } & Age (in years) & 19.93 & 1.72 & 19.10 & 0.73 & 19.33 & 1.15 \\
\cline { 2 - 8 } & Body weight $(\mathrm{kg})$ & 74.43 & 10.14 & 57.49 & 8.18 & 62.19 & 11.58 \\
\cline { 2 - 8 } & Body height $(\mathrm{m})$ & 1.80 & 0.06 & 1.67 & 0.06 & 1.71 & 0.08 \\
\hline \multirow{3}{*}{ BUT } & Age (in years) & 20.41 & 1.80 & 20.69 & 2.76 & 20.53 & 2.28 \\
\cline { 2 - 8 } & Body weight $(\mathrm{kg})$ & 67.52 & 12.69 & 62.91 & 9.86 & 65.41 & 11.67 \\
\cline { 2 - 8 } & Body height $(\mathrm{m})$ & 1.72 & 0.08 & 1.70 & 0.07 & 1.71 & 0.07 \\
\hline \multirow{3}{*}{ Portugal } & Age (in years) & 20.89 & 2.10 & 20.52 & 2.31 & 20.72 & 2.21 \\
\cline { 2 - 8 } & Body weight $(\mathrm{kg})$ & 72.04 & 9.10 & 58.13 & 8.05 & 65.43 & 11.07 \\
\cline { 2 - 8 } & Body height $(\mathrm{m})$ & 1.77 & 0.06 & 1.64 & 0.06 & 1.70 & 0.09 \\
\hline
\end{tabular}

Source: own study.

M-mean; SD-standard deviation well as work or leisure. The questions relate to the time spent sitting, walking or performing moderate or intense activities by the respondent. According to the IPAQ rules, the duration of the efforts included in the survey should be at least 10 minutes (without a break). Intensive physical exertion is compared to lifting heavy objects or climbing stairs; this type of exertion is accompanied by strong breathing and an increased heart rate. Moderate exertion should be understood as performing activities such as lifting light objects or cycling at a normal pace. During this effort, it can be observed that breathing and heart rate are slightly accelerated $[16,17,18$, 19]. MET (Metabolic Equivalent of Task) intensity factors are used to assess the types of activity listed in the questionnaire. This parameter corresponds to multiple metabolisms at rest, determined based on oxygen uptake, which amounts to $3.5 \mathrm{ml}$ of oxygen per one kilogram of body weight of $70 \mathrm{~kg}$ of a man during one minute [20,21].

Concerning the short version of the IPAQ, the MET value is 3.3 for walking-related activities, 4.0 for moderate activities and 8.0 for intensive activities. To express a specific physical activity in the MET unit - minutes/week, multiply the activity coefficient of an activity given by the number of days it is performed during the week and the duration given in minutes (during one day). Weekly average physical exercise is calculated by summing-up the results of all types of physical activities and is expressed in MET units - minutes/week. Based on the results of physical activity, those surveyed can be qualified into one of three levels of activity: high, sufficient or insufficient. A high level includes individuals who have performed intense physical activity for three or more days (a total of at least,500 MET minutes/week), or for seven or more days of combined efforts (walking, moderate or intense effort) exceeding 3,000 MET minutes/week. Individuals classified as sufficiently qualified are who have performed intense physical activity lasting at least 20 minutes per day, or a minimum of five days per week of moderate or walking effort, lasting not less than 30 minutes a day, or who performed a combination of physical exertion (walking, moderate or intense) exceeding $600 \mathrm{MET}$ - minutes/week for at least five days. An insufficient level was characterized by individuals who did not perform any physical effort, or were not qualified to a sufficient or high level [22, 23].

There is also a long-form of the IPAQ questionnaire which consists of five independent parts $[24,25,26]$. Both the long and short IPAQ questionnaires are reliable tools for collectingdatdistributor

Statistical analysis was conducted using the IBM SPSS Statistics programme (StatSoft Polska). Appropriate statistical procedures were used to verify the hypotheses. Two independent groups were compared with the Mann-Whitney $\mathrm{U}$ test. The Kruskal-Wallis test was used to compare more than two independent groups. In the case of demonstrated differences, multiple comparisons were made. The analysis also used the Bonferroni correction. Correlations between the qualitative variables were analyzed using the chi-square test of independence.

\section{RESULTS}

With reference to the men and women studying at the MU in Lublin and UBI in Portugal, the dominant activity level was high, $60.2 \%$ and $51.8 \%$, respectively. In the group of BUT 
students, sufficient activity prevailed $-30.5 \%$ of the respondents. An insufficient activity level was characterized by $2.8 \%$ of MU students, $23.7 \%$ of BUT students and $12.7 \%$ of surveyed Portuguese students. The differences were statistically significant $(\mathrm{p}<0.05)$.

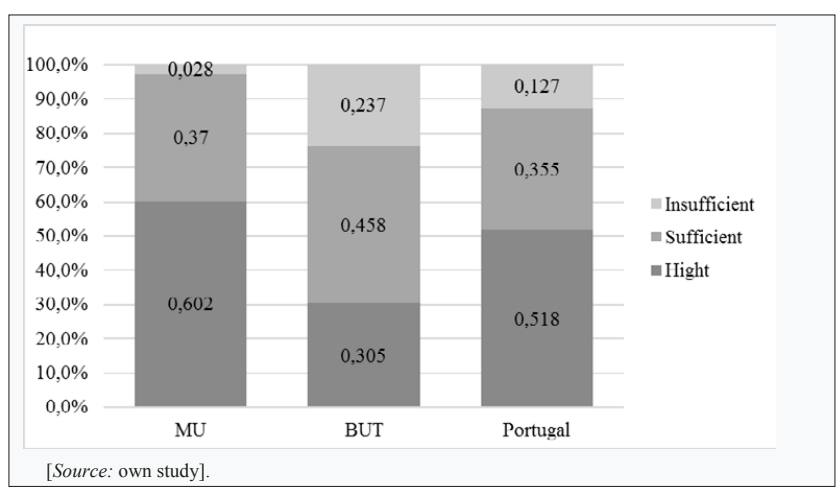

Figure 1. Levels of physical activity of Polish MU and BUT students, and Portuguese UBI students excluding gender $(n=823)$ Pearson's chi- squared test value: $x^{2}=$ 33,$560 ; \mathrm{p}<0.001$

Considering the gender of respondents, statistically significant $(\mathrm{p}<0.05)$ differences were observed in the activity levels among Portuguese students. A sufficient level of physical activity was characterized by a higher percentage of men than women. Regarding the high level, women constituted a larger group compared to men.

Taking into account the MU and BUT students, a sufficient level of activity was characterized by a higher percentage of women than men. The greater percentage of men was characterized by a higher level of physical activity, in comparison to women, both in the group of MU and BUT students. The differences were not statistically significant (p>0.05). (Tab. 2).

Table 2. Physical activity levels of Polish MU and BUT students, and UBI Portuguese students compared by gender $(n=823)$

\begin{tabular}{lccccccccc}
\hline & \multicolumn{1}{c}{ MU } & \multicolumn{1}{c}{ BUT } & \multicolumn{3}{c}{ UBI } \\
\cline { 2 - 11 } Physical activity & $\mathrm{M}$ & $\mathrm{F}$ & $\mathrm{T}$ & $\mathrm{M}$ & $\mathrm{F}$ & $\mathrm{T}$ & $\mathrm{M}$ & $\mathrm{F}$ & $\mathrm{T}$ \\
& $\%$ & $\%$ & $\%$ & $\%$ & $\%$ & $\%$ & $\%$ & $\%$ & $\%$ \\
\hline High & 73.3 & 55.1 & 60.2 & 31.3 & 29.6 & 30.5 & 46.6 & 56.4 & 51.8 \\
\hline $\begin{array}{l}\text { Moderate } \\
\text { (sufficient) }\end{array}$ & 23.3 & 42.3 & 37.0 & 37.5 & 55.6 & 45.8 & 37.5 & 33.8 & 35.5 \\
\hline $\begin{array}{l}\text { Low } \\
\text { (insufficient) }\end{array}$ & 3.3 & 2.6 & 2.8 & 31.3 & 14.8 & 23.7 & 15.9 & 9.9 & 12.7 \\
\hline
\end{tabular}
Chi-Pearson's
squared test value: $\quad x^{2}=3.345 ; p=0.188 \quad x^{2}=5.446 ; p=0.066 \quad x^{2}=7.543 ; p=0.023$

Source: own study

F-female; M-male, T- total

Next, the highest average values of total energy expenditure among men and women were reported among students at MU, followed by UBI and BUT students. In relation to total activity, statistically significant differences were observed between the compared pairs of student group, BUTPortuguese and BUT-MU ( $\mathrm{p}<0.05)$. Table 3 presents the total energy expenditure of the examined people, including gender and statistical significance.

In relation to intensive physical activity, both men and women studying at BUT had the lowest average energy
Table 3. Total physical activity of MU, BUT and UBI students by gender [MET-minutes/week]

\begin{tabular}{|c|c|c|c|c|c|c|}
\hline \multicolumn{7}{|l|}{$\mathrm{MU}$} \\
\hline \multicolumn{2}{|l|}{ Physical activity } & M & $\mathrm{Me}$ & SD & Min & Max \\
\hline & M & 5368.63 & 4565.00 & 3638.54 & 504.00 & 13038.00 \\
\hline \multirow[t]{2}{*}{ Total } & $\mathrm{F}$ & 3600.79 & 3141.50 & 2270.89 & 528.00 & 11838.00 \\
\hline & Total & 4091.86 & 3346.00 & 2816.39 & 504.00 & 13038.00 \\
\hline \multicolumn{7}{|l|}{ BUT } \\
\hline \multirow[t]{2}{*}{ Physical activity } & & M & $\mathrm{Me}$ & SD & Min & Max \\
\hline & M & 2399.99 & 1399.50 & 2591.74 & 0.00 & 14691.00 \\
\hline \multirow[t]{2}{*}{ Total } & $\mathrm{F}$ & 2725.78 & 1826.25 & 2523.58 & 230.00 & 11172.00 \\
\hline & Total & 2549.08 & 1670.25 & 2555.06 & 0.00 & 14691.00 \\
\hline \multicolumn{7}{|l|}{ Portugal } \\
\hline \multirow[t]{2}{*}{ Physical activity } & & M & $\mathrm{Me}$ & SD & Min & Max \\
\hline & M & 3963.32 & 3399.75 & 2984.54 & 0.00 & 14796.00 \\
\hline \multirow[t]{2}{*}{ Total } & $\mathrm{F}$ & 3237.15 & 2556.00 & 2768.63 & 0.00 & 14262.00 \\
\hline & Total & 3619.09 & 2862.00 & 2904.56 & 0.00 & 14796.00 \\
\hline \multicolumn{2}{|c|}{ Total physical activity } & \multicolumn{5}{|c|}{ H Kruskal-Wallis test } \\
\hline \multicolumn{2}{|l|}{ Pair comparisons } & \multicolumn{2}{|c|}{ Test statistics Stä } & ndard error & \multicolumn{2}{|c|}{ Significance adjusted } \\
\hline \multicolumn{2}{|l|}{ BUT-Portugal } & \multicolumn{2}{|c|}{-112.037} & 23.949 & \multicolumn{2}{|c|}{$<0.001$} \\
\hline \multicolumn{2}{|l|}{ BUT-MU } & \multicolumn{2}{|c|}{165.451} & 31.657 & \multicolumn{2}{|c|}{$<0.001$} \\
\hline \multicolumn{2}{|l|}{ Portugal-MU } & \multicolumn{2}{|c|}{53.413} & 24.858 & \multicolumn{2}{|c|}{0.095} \\
\hline
\end{tabular}

expenditure compared to women and men studying at UBI in Portugal and MU in Poland (Tab. 4). Considering the intensive activity, statistically, significant differences were

Table 4. Differences in intensive physical activity of Polish MU and BUT students, and Portuguese UBI students by gender [MET-minutes / week]

\begin{tabular}{|c|c|c|c|c|c|c|}
\hline \multicolumn{7}{|l|}{$\mathrm{MU}$} \\
\hline \multicolumn{2}{|l|}{ Physical activity } & M & $\mathrm{Me}$ & SD & Min & Max \\
\hline & M & 2113.33 & 1440.00 & 2009.52 & 0.00 & 6000.00 \\
\hline \multirow[t]{2}{*}{ Intensive } & $\mathrm{F}$ & 1240.00 & 960.00 & 1275.50 & 0.00 & 5760.00 \\
\hline & Total & 1482.59 & 960.00 & 1555.52 & 0.00 & 6000.00 \\
\hline \multicolumn{7}{|l|}{ BUT } \\
\hline \multirow[t]{2}{*}{ Physical activity } & & M & $\mathrm{Me}$ & SD & Min & Max \\
\hline & M & 970.88 & 320.00 & 1946.09 & 0.00 & 12000.00 \\
\hline \multirow[t]{2}{*}{ Intensive } & $\mathrm{F}$ & 828.74 & 360.00 & 1167.57 & 0.00 & 4800.00 \\
\hline & Total & 905.83 & 360.00 & 1631.53 & 0.00 & 12000.00 \\
\hline \multicolumn{7}{|l|}{ Portugal } \\
\hline \multirow[t]{2}{*}{ Physical activity } & & M & $\mathrm{Me}$ & SD & Min & Max \\
\hline & M & 1780.69 & 1440.00 & 1904.47 & 0.00 & 13800.00 \\
\hline \multirow[t]{2}{*}{ Intensive } & $\mathrm{F}$ & 1211.42 & 720.00 & 1501.40 & 0.00 & 9600.00 \\
\hline & Total & 1510.83 & 960.00 & 1747.08 & 0.00 & 13800.00 \\
\hline \multicolumn{2}{|c|}{ Intensive physical activity } & \multicolumn{5}{|c|}{ H Kruskal-Wallis test } \\
\hline \multicolumn{2}{|l|}{ Pair comparisons } & \multicolumn{2}{|c|}{ Test statistics St } & ndard error & \multicolumn{2}{|r|}{$\begin{array}{c}\text { Significance } \\
\text { adjusted }\end{array}$} \\
\hline \multicolumn{2}{|l|}{ BUT-Portugal } & \multicolumn{2}{|c|}{-102.478} & 23.625 & \multicolumn{2}{|r|}{$<0.001$} \\
\hline \multicolumn{2}{|l|}{ BUT-MU } & \multicolumn{2}{|c|}{111.544} & 31.228 & \multicolumn{2}{|r|}{0.001} \\
\hline \multicolumn{2}{|l|}{ Portugal-MU } & \multicolumn{2}{|l|}{9.066} & 24.521 & \multicolumn{2}{|r|}{1.000} \\
\hline
\end{tabular}


observed between the compared pairs of BUT- Portuguese and BUT- MU students $(\mathrm{p}<0.05)$.

Women studying at BUT had the highest values of energy

Table 5. Differences in moderate physical activity of Polish MU and BUT students, and Portuguese UBI students by gender [MET-minutes / week]

\begin{tabular}{|c|c|c|c|c|c|c|}
\hline $\mathrm{MU}$ & & & & & & \\
\hline Physical activity & & M & $\mathrm{Me}$ & SD & Min & $\operatorname{Max}$ \\
\hline & M & 1382.00 & 960.00 & 1440.21 & 0.00 & 5040.00 \\
\hline \multirow[t]{2}{*}{ Moderate } & $\mathrm{F}$ & 687.95 & 240.00 & 996.84 & 0.00 & 4800.00 \\
\hline & Total & 880.74 & 480.00 & 1172.52 & 0.00 & 5040.00 \\
\hline \multicolumn{7}{|l|}{ BUT } \\
\hline \multirow[t]{2}{*}{ Physical activity } & & M & Me & SD & Min & $\operatorname{Max}$ \\
\hline & M & 429.06 & 220.00 & 609.00 & 0.00 & 2880.00 \\
\hline \multirow[t]{2}{*}{ Moderate } & $\mathrm{F}$ & 711.48 & 440.00 & 952.37 & 0.00 & 4320.00 \\
\hline & Total & 558.31 & 360.00 & 794.07 & 0.00 & 4320.00 \\
\hline \multicolumn{7}{|l|}{ Portugal } \\
\hline \multirow[t]{2}{*}{ Physical activity } & & M & $\mathrm{Me}$ & SD & Min & Max \\
\hline & M & 841.80 & 480.00 & 1204.45 & 0.00 & 8784.00 \\
\hline \multirow[t]{2}{*}{ Moderate } & $\mathrm{F}$ & 671.10 & 360.00 & 1026.61 & 0.00 & 7200.00 \\
\hline & Total & 760.88 & 360.00 & 1125.97 & 0.00 & 8784.00 \\
\hline \multicolumn{7}{|c|}{$\mathrm{H}$ Kruskal-Wallis test } \\
\hline \multirow[t]{2}{*}{ Physical activity } & $\mathrm{MU}$ & & & ortugal & $\mathrm{H}$ & $\mathrm{p}$ \\
\hline & \multicolumn{4}{|c|}{ Average rank } & & \\
\hline Moderate & 434.7 & 36 & .18 & 16.35 & 5.138 & 0.077 \\
\hline
\end{tabular}

Source: own study.

M-male; F-female

M - mean; Me - median; SD- standard deviation; Min- minimum; Max- maximum.

Table 6. Differences in physical activity related to the walking of Polish MU and BUT students, and Portuguese UBI students by gender [METminuets / week]

\begin{tabular}{|c|c|c|c|c|c|c|}
\hline \multicolumn{7}{|l|}{$\mathrm{MU}$} \\
\hline Physical activity & & M & Me & SD & Min & $\operatorname{Max}$ \\
\hline \multirow{3}{*}{ Walking } & M & 1873.30 & 1386.00 & 1263.89 & 0.00 & 4158.00 \\
\hline & $\mathrm{F}$ & 1672.85 & 1386.00 & 1237.11 & 0.00 & 4158.00 \\
\hline & Total & 1728.53 & 1386.00 & 1241.95 & 0.00 & 4158.00 \\
\hline \multicolumn{7}{|l|}{ BUT } \\
\hline Physical activity & & M & Me & SD & Min & Max \\
\hline \multirow{3}{*}{ Walking } & M & 1000.05 & 594.00 & 1332.36 & 0.00 & 5544.00 \\
\hline & $\mathrm{F}$ & 1185.56 & 693.00 & 1316.65 & 0.00 & 6930.00 \\
\hline & Total & 1084.94 & 660.00 & 1322.79 & 0.00 & 6930.00 \\
\hline \multicolumn{7}{|l|}{ Portugal } \\
\hline Physical activity & & M & $\mathrm{Me}$ & SD & Min & Max \\
\hline \multirow{3}{*}{ Walking } & M & 1340.84 & 792.00 & 1507.85 & 0.00 & 11088.00 \\
\hline & $\mathrm{F}$ & 1354.63 & 742.50 & 1664.42 & 0.00 & 11088.00 \\
\hline & Total & 1347.38 & 792.00 & 1582.67 & 0.00 & 11088.00 \\
\hline Walking & & \multicolumn{5}{|c|}{ H Kruskal-Wallis test } \\
\hline Pair comparisons & & \multicolumn{2}{|c|}{ Test statistics } & $\begin{array}{l}\text { Standard } \\
\text { error }\end{array}$ & \multicolumn{2}{|c|}{$\begin{array}{c}\text { Significance } \\
\text { adjusted }\end{array}$} \\
\hline BUT-Portugal & & \multicolumn{2}{|c|}{$-50,544$} & 23,937 & \multicolumn{2}{|r|}{0,104} \\
\hline BUT-MU & & \multicolumn{2}{|l|}{170,657} & 31,641 & \multicolumn{2}{|c|}{$<0,001$} \\
\hline Portugal-MU & & \multicolumn{2}{|l|}{120,112} & 24,845 & \multicolumn{2}{|c|}{$<0,001$} \\
\hline
\end{tabular}

Source: own study.

M- mean; Me - median; SD- standard deviation; Min- minimum; Max- maximum.
Table 7. Average sitting time of students during one working day [min] $(\mathrm{n}=823)$

\begin{tabular}{|c|c|c|c|c|c|c|}
\hline Sitting & & M & $\mathrm{Me}$ & SD & Min & Max \\
\hline & M & 349,00 & 330.00 & 273.08 & 0.00 & 1200.00 \\
\hline \multirow[t]{3}{*}{$\mathrm{MU}$} & $\mathrm{F}$ & 261.41 & 300.00 & 211.67 & 0.00 & 720.00 \\
\hline & Total & 287.74 & 300.00 & 232.40 & 0.00 & 1200.00 \\
\hline & M & 381.09 & 420.00 & 150.91 & 30.00 & 600.00 \\
\hline \multirow[t]{3}{*}{ BUT } & $\mathrm{F}$ & 340.56 & 360.00 & 140.42 & 60.00 & 660.00 \\
\hline & Total & 362.54 & 370.00 & 146.99 & 30.00 & 660.00 \\
\hline & M & 391.40 & 360.00 & 164.96 & 30.00 & 900.00 \\
\hline \multirow[t]{2}{*}{ Portugal } & $\mathrm{F}$ & 395.32 & 360.00 & 169.83 & 0.00 & 1020.00 \\
\hline & Total & 393.26 & 360.00 & 167.15 & 0.00 & 1020.00 \\
\hline Sitting & \multicolumn{6}{|c|}{ H Kruskal-Wallis test } \\
\hline Pair comparisons & & Test statistics & \multicolumn{2}{|c|}{ Standard error } & \multicolumn{2}{|c|}{$\begin{array}{l}\text { Significance } \\
\text { adjusted }\end{array}$} \\
\hline BUT-Portugal & & -97.511 & \multicolumn{2}{|c|}{31.445} & \multicolumn{2}{|c|}{0.006} \\
\hline BUT-MU & & -121.002 & \multicolumn{2}{|c|}{24.694} & \multicolumn{2}{|c|}{$<0.001$} \\
\hline Portugal-MU & & -23.490 & \multicolumn{2}{|c|}{23.792} & \multicolumn{2}{|c|}{0.970} \\
\hline
\end{tabular}

Source: own study.

$\mathrm{M}$ - male; $\mathrm{F}$-female.

M - mean; Me - median; SD- standard deviation; Min- minimum; Max- maximum.

expenditure related to moderate activity compared to women studying at MU and in Portugal (Tab. 5). In the male group, the highest average values of the same activity were recorded among MU students, followed by Portuguese UBI students and Polish BUT students. The differences were not statistically significant $(\mathrm{p}>0.05)$.

In terms of walking-related activity, the lowest average values of weekly energy expenditure were recorded, both for men and women, among BUT students. Subsequently, the highest average values of the same activity were recorded in the group of men and women studying at MU. Without taking into account the gender of the respondents, statistically significant differences were observed between the compared pairs of the Polish MU - BUT students, and Portuguese UBI MU students $(\mathrm{p}<0.05)$ with regard to physical activity related to walking. The students at MU obtained the highest average results of energy consumption compared to PortugueseUBI students and BUT (Tab. 6).

Both male and female Portuguese UBI students spent most of their time sitting during one working day, compared to $\mathrm{MU}$ and BUT (Tab. 7). Apart from the gender of the respondents, statistically significant differences were noted between the compared pairs of Polish MU-BUT and Portuguese UBI Polish MU student groups ( $\mathrm{p}<0.05)$

\section{DISCUSSION}

The conducted research indicates that the lowest average values of energy expenditure for both women and men studying at the Polish MU and BUT and the Portuguese UBI concerned moderate physical activity. Recent studies demonstrated that the lowest values of average activity related to moderate effort [33].

Based on own study, it has been shown that the most common form of activity in the group of women studying at the Polish MU and BUT, and in the Portuguese UBI was a walking-related activity; the next most frequently chosen 
type of effort was intensive effort and moderate effort. Among men studying at MU in Poland and UBI in Portugal, the highest average values of energy expenditure concerned intensive activity, followed by walking effort and moderate effort. Similar results were obtained by Bednarek et al. [34] who carried out a study on students of the Faculty of Tourism and Leisure at the University of Physical Education in Kraków, Poland, and the Adnan Menderes University in Aydin, Turkey. The highest values of the average activity of women studying in Kraków and Aydin concerned walking effort, followed by intensive activity and moderate activity. As in the case of men studying at the MU in Poland and in UBI in Portugal, students from Kraków and Aydin preferred intensive effort, followed by walking-related and moderate activity.

Garcia Puello et al. conducted a study to assess the level of physical activity of students from six universities in Barranquilla, Colombia [35]. Similar to the case of men studying at the MU in Poland and in UBI Portugal, the highest average values of energy expenditure were for intensive activity, followed by walking effort and moderate effort.

The results of the current study are consistent with the results of a study carried out by Baj-Korpak et al. [36] who analyzed the level of physical activity of students of physical education at the University of Physical Education (AWF) in Kraków. The highest average values of energy consumption were among men studying at the University of Physical Education, and similar to men studying at the Polish MU and Portuguese UBI, and concerned intensive activity, followed by walking effort and moderate effort.

The predominant level of activity of both men and women studying at the Polish MU and the Portuguese UBI was high. This pattern also persisted in the study by Vašíckovâ et al. who evaluated the level of physical activity of Czech pupils and students [37]. The dominant level of activity in this group, as in the case of students of the Polish MU and Portuguese UBI students, was high. The least numerous group of students from the Czech Republic, as in the case of students from the MU and UBI, consisted of students characterized by insufficient activity level.

Rajappan et al. conducted a study to determine the diversity of physical activity among students of the Asia Metropolitan University (AMU) in Chavas (Selangor), Malaysia [38]. Similar to the case of students at the MU in Poland and UBI in Portugal, the dominant level of activity in this group was high, followed by a sufficient level and non-performance of physical activity. The above-mentioned authors did not note any of the AMU students being characterized by an insufficient level of physical activity.

A study using the short version of the IPAQ questionnaire was also conducted by Chiang et al. [39], which involved students from universities Taiwanese students was at a sufficient level, followed by a high level and an insufficient level among the surveyed students. In relation to people studying at American universities, as in the case of people studying at the MU in Poland and UBI in Portugal, the dominant level of activity was high, followed by excessive and insufficient.

An assessment of the level of physical activity was also carried out by Piątkowska [40]. In that study, similar to the case of the Polish MU and UBI Portuguese students, both men and women, the dominant type of activity was at a high level, followed by sufficient and insufficient values.
The current study shows that a higher percentage of men than women studying at MU and BUT had a high or insufficient level of physical activity. In the context of the sufficient level, women studying at MU and BUT constituted a bigger group than men. The results of own research are consistent with those of Bergier et al. who evaluated the level of physical activity of Polish pupils and students [41]. As in the case of MU and BUT students, a higher or insufficient level was characteristic by a larger percentage of men than women. In the context of the moderate level, as in the case of MU and BUT students, women constituted a larger group compared to men.

The predominant type of activity in the group of women studying at the MU in Poland and UBI in Portugal was on a the high level. These results are in accordance with those obtained by Kaiser and Sokołowski who examined women studying at the General Academy of Land Forces (AWL) in Wrocław and Poznań, Poland [42]. Additionally, as in the case of women studying at the MU and UBI, the highest percentage of female AWL students, in Wroclaw and Poznan combined, concerned a high level of activity.

The results of the current study are consistent with the research of Morales Quispe et al. who examined third and fourth grade high school students in the Callao region of Peru. As in the case of women studying at MU and UBI, the highest percentage of female students was in high activity.

Particular interest centres on the time spent in sitting. Based on the presented study, it was found that the average sitting time during one working day was the highest in the group of Portuguese UBI students, followed by the Polish BUT and MU students. Students from UBI and BUT achieved higher results compared to those examined by Piątkowska [40]. Bergier and Ignatjeva analyzed the physical activity of students attending Polish schools in Riga, Latvia [44]. Similar to the case of women studying at MU and BUT, a lower average values of time spent on sitting was observed for girls than boys studying in Latvia.

Bergier et al. [45] also conducted research using the short version of the IPAQ questionnaire. The level of physical activity was evaluated for students of the State Higher Education School (PSW) in Biała Podlaska, Poland. Men studying in Biala Podlaska, the same as in the case of men studying at MU and BUT, were characterized by a higher average value of time spent sitting, compared to women.

\section{CONCLUSIONS}

1. Students of the Medical University (MU), as well as Portuguese students (UBI), were characterized by a high level of physical activity, while students of the Białystok University of Technology (BUT) had an adequate level of physical activity.

2. Among women studying at MU and BUT in Poland, and ast UBI in Portugal, the highest average energy expenditure values were related to walking effort.

3. Among both men and women studying at MU, BUT and UBI, the lowest average values of energy consumption were for moderate activity.

4. MU students spent less time sitting during one working day than BUT and UBI students.

5. Due to the cross-cultural nature of the study, the association between physical activity (PA) and gender cannot be precisely determined. 


\section{REFERENCES}

1. Caspersen C, Powell K, Christenson G, Physical Activity, Exercise, and Physical Fitness: Definitions and Distinctions for Health-Related Research. Public Health Rep. 1985; 100: 126-131.

2. Helmerhorst H, Brage S, Warren J, et al. A systematic review of reliability and objective criterion-related validity of physical activity questionnaires. Int J Behav Nutr Phys Act. 2012; 9: 103. https://doi. org/10.1186/1479-5868-9-103

3. Kowalski K, Rhodes R, Naylor P, et al. Direct and indirect measurement of physical activity in older adults: a systematic review of the literature. Int J Behav Nutr Phys Act 2012; 9: 148. https://doi.org/10.1186/14795868-9-148

4. Booth F, Roberts C, Laye M, et al. Lack of exercise is a major cause of chronic diseases. Compr Physiol. 2012; 2: 1143-1211. https://doi. org/10.1002/cphy.c110025

5. Lee I, Shiroma E, Lobelo F, et al. Impact of Physical Inactivity on the World's Major Non-Cmmunicable Diseases. Lancet. 2012; 380: 219-229. https://doi.org/10.1016/S0140-6736(12)61031-9

6. Pedersen B, Saltin B. Evidence for prescribing exercise as therapy in chronic disease. Scand J Med Sci Sports. 2006; 16 (Supl. 1): 3-63. https:// doi.org/10.1111/j.1600-0838.2006.00520.x

7. Kokkinos P. Physical activity, health benefits, and mortality risk. ISRN Cardiol. 2012; 2012: 718789. https://doi.org/10.5402/2012/718789

8. Cavill N, Kahlmeier S, Racioppi F. Physical activity and health in Europe: evidence for action. WHO. Denmark 2006: 1-34.

9. Haskell L, Russell R, Kenneth E. Physical Activity and Public health: Updated Recommendation for Adults from the American College of Sports Medicine and the American Heart Association. Circulation. 2007; 9: 1081-1093. https://doi.org/10.1161/CIRCULATIONAHA.107.185649

10. Helou K, El Helou N, Mahfouz M. Validity and reliability of an adapter arabic version of the long international Physical activity questionnaire. BMC Public Health. 2018; 18: 49. https://doi.org/10.1186/s12889-0174599-7

11. Nelson M, Rejewski W, Blair S. Physical Activity and Public Health in Older Adults: Recommendation from the American College of Sports Medicine and the American Heart Association. MSSE. 2007; 39: 14351445. https://doi.org/10.1249/mss.0b013e3180616aa2

12. WHO physical activity recommendations, https://www.who.int/en/ news-room/fact-sheets/detail/physical-activity (access 10. 11. 2020).

13. Atkin A, Gorely T, Clemes S, et al. Methods of Measurement in epidemiology: Sedentary Behaviour. Int J Epidemiol. 2012; 41: 1460 1471. https://doi.org/10.1093/ije/dys118

14. Grimm E, Swartz A, Hart T, et al. Comparison of the IPAQ-Short Form and accelerometry predictions of physical activity in older adults. J Aging Phys Act. 2012; 20: 64-79. https://doi.org/ 10.1123/ japa.20.1.64

15. Jefferis B, Sartini C, Lee I, et al. Adherence to physical activity guidelines in older adults, using objectively measured physical activity in a population-based study. BMC Public Health. 2014; 14: 382. https:// doi.org/10.1186/1471-2458-14-382

16. Biernat E, Piatkowska M. The usefulness of descriptive statistics in the interpretation of data on accupational Physical activity of Poles. Med Pr. 2014; 6: 743-753. https://doi.org/10.13075/mp.5893.00085

17. Biernat E, Stupnicki R. Reviev of international questionnaires used in physical activity testing. Phys Edu Sport. 2005; 49: 61-73.

18. Finger J, Tafforeau J, Gisle L, et al. Development of the European Health Interview Survey - Physical Activity Questionnaire (EHIS-PAQ) to monitor physical activity in the European Union. Arch Public Health. 2015; 73: 59. https://doi.org/10.1186/s13690-015-0110-z

19. Scholes S, Bridges S, Ng Fat L, et al. Comparison of the Physical Activity and Sedentary Behaviour Assessment Questionnaire and the ShortForm International Physical Activity Questionnaire: An Analysis of Health Survey for England Data. PLoS One. 2016; 11: e0151647. https:// doi.org/10.1371/journal.pone.0151647

20. Ng S. Popkin B. Time Use and Physical Activity: A Shift Away from Movement across the Globe. Obes Rev. 2012; 13: 659-680. https://doi. org/10.1111/j.1467-789X.2011.00982.x

21. Żołąź J, Majerczak J. The impact of aging on human physical performance. In: Marchewka A. Dąbrowski Z. Żołądź J. (eds.) Aging physiology Prevention and rehabilitation. Warsaw: PWN Scientific publishing House; 2013. p. 363-370.

22. Biernat E, Piątkowska M. Overestimation of physical activity by long IPAQ in a Polish nationwide study. Hygeia Public Health. 2016; 51: 87-95. https://doi.org/10.13140/RG.2.1.1448.7445

23. Biernat E, Stupnicki, Gajewski A. International Physical Activity Questionnaire (IPAQ)- polish version. Phys Edu Sport. 2007; 51: 47-54.
24. Ács P, Betlehem J, Oláh A, et al. Measurement of public health benefits of Physical activity: validity and reliability study of the international Physical activity questionnaire in Hungary. BMC Public Health 2020; 20: 1198. https://doi.org/10.1186/s12889-020-08508-9

25. Biernat E. International Physical Activity Questionnaire - polish long version. Medycyna Sportowa. 2013; 29: 1-15.

26. Craig C, Marshall A, Sjöström M. International Physical Activity Questionnaire 12-Country Reliability and Validity. Med Sci Sports Exerc. 2003; 35: 1381- 1395. https://doi.org/10.1249/01. MSS.0000078924.61453.FB

27. Cleland C, Ferguson S, Ellis G, et al. Validity of the International Physical Activity Questionnaire (IPAQ) for assessing moderate-tovigorous physical activity and sedentary behaviour of older adults in the United Kingdom. BMC Med Res Methodol. 2018; 18: 176. https:// doi.org/10.1186/s12874-018-0642-3

28. Hong T, Trang N, van de Ploeg $\mathrm{H}$, et al. Validity and reliability of a Physical activity questionnaire for Vietnamese adolescents. Int J Behav Nutr Phys Act. 2012; 9: 93. https://doi.org/10.1186/1479-5868-9-93

29. Lee H, Macfarlane J, Lam T. Validity of the international physical activity questionnaire short form (IPAQ-SF): A systematic review. Int J Behav Nutr Phys Act. 2011; 8: 115: 1-11. https://doi.org/10.1186/14795868-8-115

30. Tran D, Lee A, Au TB, et al. Reliability and validity of the International Physical Activity Questionnaire-Short Form for older adults in Vietnam. Health Promot J Austr. 2013; 24: 126-131. https://doi.org/10.1071/ HE13012

31. Van Holle V, De Bourdeaudhuij I, Deforche B, et al. Assessment of physical activity in older Belgian adults: validity and reliability of an adapted interview version of the long International Physical Activity Questionnaire (IPAQ-L). BMC Public Health. 2015; 15: 433. https://doi. org/10.1186/s12889-015-1785-3

32. Kim Y, Park I, Kang M. Convergent validity of the International Physical Activity Questionnaire (IPAQ): meta-analysis. Public Health Nutr. 2012; 16: 440-452. https://doi.org/10.1017/S1368980012002996

33. Fagaras S, Radu L, Vanvu G. The level of Physical Activity of University Students. Elsevier Procedia-Social and behavioral Sciences. 2015; 197: 1454-1457. https://doi.org/10.1016/j.sbspro.2015.07.094

34. Bednarek J, Pomykała S, Bigosińska M, et al. Physical activity of polish and Turkish University students as assessed by IPAQ. Central European Journal of Sports Sciences and Medicine. 2016; 4: 13-22. https://doi. org/10.18276/cej.2016.4-02

35. García Puello F, Herazzo Beltrán Y, Tuesca Molina R. Factore sociodemográficos y motivacionales asocionales a la actividad física en estudiantes universitarios. Rev Med Chile. 2015; 143: 1411-1418. http://dx.doi.org/10.4067/S0034-98872015001100006

36. Baj-Korpak J, Soroka A, Sudoł G. The level of physical activity of students from the University School of Physical Education in Cracow Scientific Yearbooks of Graduate School of Physical Education and Tourism. 2014; 10: 9-15.

37. Vašíčkovâ J, Frömel K, Nykodým J. Physical activity recommendation and its association with demographic variables in Czech university students. Acta Univ Palacki Olomuc Gymn. 2008; 2: 75-84.

38. Rajappan R, Salvaganapatthy K, Liew L. Physical activity level among university students: a cross sectional survey. Int J Physiother Res. 2015; 3: 1336-1343. https://doi.org/10.16965/ijpr.2015.202

39. Ciang L, Zhang P, Casebolt K, et al. A Comparison of College Students' Physical Activity levels between Taiwan and the United States. Asian Journal of Exercise\&Sports Science. 2013; 2: 49- 59.

40. Piątkowska M. Age-related changes in physical activity patterns in Poland. Antropomotoryka. 2012; 59: 17-29.

41. Bergier J, Kapka-Skrzypczak L, Biliński P, et al. Physical activity of Polish adolescents and young adults according to IPAQ: a population based study. Ann Agric Environ Med 2012; 1: 109-115.

42. Kaiser A, Sokołowski M. Health potential of female candidates to the professional military service. Biomedical Human Kinetics. 2011; 3: 96-100. https://doi.org/10.2478/v10101-011-0021-6

43. Morales Quispe J, Añez Ramos R, Suarez Orè C. Nivel de actividad física en adolescents de un distrito de la region callao. Rev Peru Med Exp Salud Publica. 2016; 33: 471- 477. http://dx.doi.org/10.17843/ rpmesp.2016.333.2312

44. Bergier J. Ignatjeva A. Differentiation of physical activity according among girls and boys of polish schools in Latvia. Scientific Yearbooks of Graduate School of Physical Education and Tourism. 2017; 2: 20-31.

45. Bergier B, Stępień E, Niźkowska E, et al. Physical activity of male and female students of the State Higher Vocational School in Biała Podlaska, Poland. Med Og Nauk Zdr. 2014; 2: 166-170. https://doi. org/10.5604/20834543.1112232 